\title{
ANALYSIS OF ECONOMIC LOSS OF FLOOD VICTIM BROILER FARMS
}

\author{
M. R. Hossain ${ }^{1}$, A. Ali ${ }^{2}$, A. H. M. S. Rahman ${ }^{2}$ and A. S. Apu ${ }^{2}$
}

\begin{abstract}
The present study was carried out to investigate the economic loss of flood victim broiler farms and also to explore the relationship between various independent variables with economic loss of flood victim broiler farms (dependent variable). The independent variables were considered as education, family size, occupation, farm size, feed sources, types of vaccine and medicine used and marketing place of broiler. Data were collected through interview schedule from 43 broiler farmers at 6 upazila of Netrokona district after flood. Most of the farmers were between 30-40 years of age and had small sized (3-6) family depending mainly on combined agriculture and poultry husbandry. They had small sized farms (500-1000 birds/ farm). They did not use any vaccine but use Antibiotic + Antifungal as medicine in case of disease. According to three-fourth of the farmers, the mortality rate of the broilers were within 1-100 nos. Marketable age of broiler was mostly 23-27 days and most of the farmers sold their broiler to the local market. During natural calamities, the price of chick, feed and transportation cost were suddenly increased. Majority of the farmers had to buy their chicks and feeds at a higher cost (2.0-2.9 Tk. more/chick; 0.6 Tk. more/kg feed) after the flood. They faced a loss of $13 \mathrm{Tk}$.. and above per kg broiler. The overall analysis also indicated that about half of the farms $(51.2 \%)$ faced high economic loss (1500 Tk. and above) due to flood. From the various correlation analysis, it was revealed that family size, occupation, feed sources and types of vaccine used had no significant relationship but education, farm size, types of medicine and marketing place of broiler had significant $(\mathrm{P}<0.01)$ and negative correlation with economic loss of flood victim broiler farms.
\end{abstract}

Key words : Economic loss, Dependent variable, Independent variable, Flood victim

\section{Introduction}

The small scale poultry farming in the rural area can significantly contribute in earning cash within shortest possible time and to remove malnutrition among the rural people. In this regard, broiler industry might be a promising industry to alleviate the unemployment problem as well as to take the challenge of $21^{\text {st }}$ century and meet the scarcity of animal protein within shortest possible time in Bangladesh. Commercial broiler production has become a specialized and speedy business at the present time for the people of third world country like Bangladesh. A good number of large, medium and small broiler farms have already been established in different parts of the country and also in Netrokona district. In Bangladesh, broiler meat has a great demand as compared to other meat because of the socio-economic limitation and religious taboos in case of pork and beef (Jabbar and Green, 1983). Recently, government and non-government organizations also have undertaken intensive

\footnotetext{
${ }^{1}$ Department of Poultry Science, Bangladesh Agricultural University (BAU), Mymensingh-2202, Bangladesh

${ }^{2}$ Department of Animal Breeding and Genetics, Bangladesh Agricultural University (BAU), Mymensingh-2202, Bangladesh
}

(Received : March 11, 2008) 
Bang. J. Anim. Sci. 2008, 37 (1)

programmes to increase broiler farms. Regular poultry raising among the rural families would help supply meat for people and can render regular cash and capital for self-employment.

But it is a matter of great concern that Bangladesh terribly suffers from flood every year. Government of Bangladesh cites flood as the main cause for not achieving the target economic growth. Now, it is a professional challenge for the poultry specialists who are responsible for poultry rearing, operation and maintenance. The suffering condition of broiler farmer is very serious during the flood. Most of the broiler farmer are not trained for broiler rearing. So, they cannot take any precaution measures for the upcoming flood. At the time of flood, the broiler farm which are situated at low land area is sunk into the flood water and they cannot be able to transfer their broiler to high land for short period of time. They have to sell their broiler at the local market at a very low price. They face marketing problem as well as high economic loss at that time. But, there have limited information on the economic loss of flood victim broiler farms. So the present study was designed : i. To analyze the economic status of broiler farms before and after flood, ii. To assess the effect of education, family size, occupation, farm size, feed sources, use of vaccine, medicine and market place of broilers on economic performance of broiler farms and iii. To determine the problem confrontation of the flood victim broiler farms.

\section{Materials and Methods}

Six upazilas of Netrokona district were selected namely Purbadhala, Durgapur, Madan, Mohanganj, Barhatta and Netrokona Sadar. A total of 43 broiler farms (sampling unit) was taken in which 12 from Netrokona sadar, 8 from Purbadhala, 10 from Madan, 5 from Mohanganj, 5 from Dhurgapur and 3 from Barhatta upazilla. An interview schedule (in Bengali) was carefully designed keeping the objectives of the study in view. The schedule contained both open and close form question. Most easy, simple and direct question were used to obtain the authentic information. The data were collected through face to face interview with the owner of the selected farms. During data collection, the objectives of the study were clearly explained to the respondent so that they could respond freely. The broiler farmer were interviewed both at their farm and home. The data were collected from October to November, 2004 after flood. The independent variables of the study were age, education, family size, use of vaccine, use of medicine, income before and after flood. However, the dependent variable of the study was considered as economic loss of flood victim broiler farms in Netrokona district. For describing the variables, suitable scales were employed to measure the dependent and independent variables.

\section{Measurement of independent variable}

Age

Education

Family size
: Age of the broiler farmer was calculated from his time of birth to the time of interview and was measured in terms of years.

: Education of the respondent was measured by calculating the year of schooling. Respondent, who did not go to school but could read, write or sign only was given score 1 whereas score of zero (0) was given to that respondent who was unable to read and write.

: Family size of the respondent was measured in terms of actual number of members in the family including his wife, children and other dependents. One score was assigned for each member of the family. Total number of members in a respondent's family constituted the family size score. 

Occupation : Occupation of the respondent was measured in terms of type of occupation where score 4 was given for service, 5 for Agriculture/Poultry farming and 6 for Poultry Farming/Service.
Income level : Before flood, income of the respondent was measured in terms of actual income from boiler rearing. On the other hand, after flood income of the respondent was measured in terms of actual income/loss from boiler rearing.
Use of vaccine $\quad$ : It is measured in terms of actual number of vaccine applied to the broiler by the time.
Use of medicine $\quad$ : Use of medicine of broiler by the respondent measured in terms of actual number of medicine applied to the broiler including anti-bacterial, anti-parasitic, anti-fungal and other disinfectants.

\section{Measurement of dependent variable}

The dependent variable of the present study was "Economic loss of flood victim broiler farms in Netrokona district." The interview schedule was prepared with 4-point rating scale for dependent variables to make it easy for all type of respondent to answer. Based on the 4-point rating scale, scoring in respect of the economic loss of broiler by the broiler farmer was done. This score of economic loss on 15 selected losses problem could range from 0 to 3 where 0 indicating no economic loss and 3 indicating highly economic loss.

\section{Statistical analysis}

The data collected for the study were coded, compiled, tabulated and analyzed in accordance with the objectives of the study. Descriptive statistics such as number, percentage distribution, mean, standard deviation etc. were used in describing the dependent and independent variables. Correlation analysis was performed to explore the relationship between dependent and independent variables.

\section{Results and Discussion}

\section{Selected characteristics of the broiler farmer}

The study related to the characteristics of the broiler farmers showed that highest percentage (72.1\%) of the broiler farmer were young i.e. 30-40 years. The age of the respondents varied from 30-60 where average age of them was 38.95 with a SD of 9.79. The education of most of the respondents $(65 \%)$ were secondary (upto S.S.C level) followed by H.S.C level $(20 \%)$ and above higher secondary education (14\%). On the basis of family size, majority (72.1\%) of the farmers belong to the small size (3-6) where the family size ranged from 3-12 with a mean of 5.60 and SD of 2.85. This is slightly higher than the national average of 5.5 (BBS, 1998). The highest percentage (51.2\%) were depend on combind agriculture and poultry husbandry among the broiler farmers (Table 1).

\section{Baseline survey of broiler farms at Netrokona district}

The baseline survey of broiler farms at Netrokona district is shown in Table 2. According to the total number of birds, the farm size was divided into three categories, small (500-1000 nos.), medium (1001-1900 nos.) and large (1901 nos. and above). From this study, it was revealed that most of the farmers $(60.5 \%)$ had small sized farms (500-1000 nos.). On the other hand, $11.6 \%$ farmers possessed medium sized farms whereas $27.9 \%$ farmers had large farms. The average number of birds was 1290.69 nos. with a standard deviation of 545.03. The sources of the broiler feed had an effect on 
Bang. J. Anim. Sci. 2008, 37 (1)

profit of broiler farm. Among the farmers of Netrokona district, 7\% farmer bought feed from Dhaka, $37.2 \%$ from local market and Netrokona, 37.2\% from Netrokona and Mymensingh and rest 18.6\% from Dhaka and Mymensingh town.

Table 1. Characteristics of the broiler farmer with categories and basic statistical values

\begin{tabular}{|c|c|c|c|c|c|c|}
\hline Characteristics & $\begin{array}{l}\text { Scoring } \\
\text { method }\end{array}$ & Categories & $\begin{array}{c}\text { Respondets } \\
(\mathrm{N}=100) \\
\text { No./percent }\end{array}$ & $\begin{array}{l}\text { Observed } \\
\text { Score }\end{array}$ & Mean & $\begin{array}{l}\text { Standard } \\
\text { deviation } \\
\text { (SD) }\end{array}$ \\
\hline \multirow{3}{*}{ Age } & \multirow{3}{*}{$\begin{array}{l}\text { No. of } \\
\text { years }\end{array}$} & Young (30-40) & 72.1 & \multirow{3}{*}{$30-60$} & \multirow{3}{*}{38.95} & \multirow{3}{*}{9.79} \\
\hline & & Middle aged (41-50) & 11.6 & & & \\
\hline & & Old (51 and above) & 16.3 & & & \\
\hline \multirow{3}{*}{ Education } & \multirow{3}{*}{$\begin{array}{l}\text { Year of } \\
\text { schooling }\end{array}$} & Secondary $(7-10)$ & 65.1 & \multirow{3}{*}{$7-14$} & \multirow{3}{*}{10.00} & \multirow{3}{*}{2.33} \\
\hline & & Higher Secondary (11-12) & 20.00 & & & \\
\hline & & $\begin{array}{l}\text { Above Higher Secondary } \\
\text { (14 and above) }\end{array}$ & 14.00 & & & \\
\hline \multirow{3}{*}{ Family size } & \multirow{3}{*}{$\begin{array}{l}\text { No. of } \\
\text { member }\end{array}$} & Small (3-6) & 72.1 & \multirow{3}{*}{$3-12$} & \multirow{3}{*}{5.60} & \multirow{3}{*}{2.85} \\
\hline & & Medium (7-8) & 11.6 & & & \\
\hline & & Large ( 9 and above) & 16.3 & & & \\
\hline \multirow{3}{*}{ Occupation } & \multirow{3}{*}{$\begin{array}{l}\text { Type of } \\
\text { occupation }\end{array}$} & Service (4) & 32.6 & \multirow{3}{*}{$4-6$} & \multirow{3}{*}{4.84} & \multirow{3}{*}{0.68} \\
\hline & & Agriculture/Poultry farming (5) & 51.2 & & & \\
\hline & & Poultry Farming/Service (6) & 16.3 & & & \\
\hline
\end{tabular}

On the basis of use of medicine, it was observed that most of the farmers $(53.5 \%)$ were interested to use antibiotic+antifungal, $30.2 \%$ only Solution (chick tonic, glucose solution and other multivitamin) and the rest use antibiotic+solution. According to the category of the vaccine used, result showed that the range of vaccine used was $0-5$ with a mean of 2.21 and standard deviation 1.3 . From this study, it was also reported that most of the broiler farmers $(51.2 \%)$ did not use any vaccine because it was costly and also had a probability of vaccine failure due to lack of cool chain. The market age of broiler ranged from 23-30 days with a mean of 26.74 days and standard deviation 2.24. The highest percentage of the farmers (65.1\%) sold their broiler within 23-27 days. The broiler farmers usually sold their broilers in different places. Among them, 55.8\% farmers sold their broilers in the local market which was considered as the highest. In broiler rearing, mortality was a critical factor which was categorized into three types: low (1-100), medium (101-200) and high (201 and above). The average mortality of birds ranged from 12-500 with a mean of 113.86 and standard deviation 47.7. According to most of the farmers $(67.4 \%)$, the mortality rate of birds was very low (1-100) in Netrokona district after flood.

\section{Economic analysis of broiler farms in relation to flood}

\section{Cost per chick}

Cost of chick is an important factor in broiler farming. During natural calamities, it was observed that the price of chick was suddenly increased. From the present study, this picture was also shown at Netrokona district. It was reported that the cost per chick was minimum Tk. 17 and maximum Tk. 18 with an average of Tk. 17.67 and standard deviation 0.47 which was increased upto Tk. 19-20 after flood. The average cost per chick was Tk. 19.5 and standard deviation was 0.50 after flood. Before flood most of the respondent (67.4\%) bought the chicks at the rate of Tk. 18/chick whereas after flood 
it was drastically increased and about $55.8 \%$ of the total repondents bought at the rate of Tk. 20 /chick (Table 3). The main cause behind the increase of chick cost after flood might be due to transportation problem and harsh environment.

Table 2. Baseline survey of broiler farms

\begin{tabular}{|c|c|c|c|c|c|}
\hline Characteristics & Categories & $\begin{array}{l}\text { Respondets } \\
(\mathrm{N}=100) \\
\text { No./percent }\end{array}$ & $\begin{array}{l}\text { Observed } \\
\text { score }\end{array}$ & Mean & $\begin{array}{c}\text { Standard } \\
\text { deviation (SD) }\end{array}$ \\
\hline \multirow{3}{*}{ Farm size } & Small (500-1000 nos.) & 60.5 & \multirow{3}{*}{$500-2200$} & \multirow{3}{*}{1290.69} & \multirow{3}{*}{545.03} \\
\hline & Medium (1001-1900 nos.) & 11.6 & & & \\
\hline & Large (1901 nos. and above) & 27.9 & & & \\
\hline \multirow{4}{*}{ Feed source } & Dhaka (4) & 7 & \multirow{4}{*}{$4-7$} & \multirow{4}{*}{5.67} & \multirow{4}{*}{0.865} \\
\hline & Local + Netrokona (5) & 37.2 & & & \\
\hline & Netrokona + Mymensingh (6) & 37.2 & & & \\
\hline & Dhaka + Mymensingh (7) & 18.6 & & & \\
\hline \multirow{3}{*}{$\begin{array}{l}\text { Type of medicine } \\
\text { used }\end{array}$} & Antibiotic + Antifungal (1-2) & 53.5 & \multirow{3}{*}{$1-4$} & \multirow{3}{*}{2.25} & \multirow{3}{*}{1.13} \\
\hline & Only solution (3) & 30.2 & & & \\
\hline & Antibiotic + solution (4) & 16.3 & & & \\
\hline \multirow{3}{*}{$\begin{array}{l}\text { Type of vaccine } \\
\text { used }\end{array}$} & No vaccine used (0) & 51.2 & \multirow{3}{*}{$0-5$} & \multirow{3}{*}{2.21} & \multirow{3}{*}{1.3} \\
\hline & Gamboro (4) & 23.3 & & & \\
\hline & ND+Gamboro (5) & 25.6 & & & \\
\hline \multirow{3}{*}{$\begin{array}{l}\text { Market age of } \\
\text { broiler }\end{array}$} & 23-27 days & 65.1 & \multirow{3}{*}{$23-30$} & \multirow{3}{*}{26.74} & \multirow{3}{*}{2.24} \\
\hline & 28-29 days & 16.3 & & & \\
\hline & 30 days and above & 18.6 & & & \\
\hline \multirow{3}{*}{$\begin{array}{l}\text { Market place of } \\
\text { broiler }\end{array}$} & Local market (1) & 55.8 & \multirow{3}{*}{$1-6$} & \multirow{3}{*}{2.70} & \multirow{3}{*}{2.04} \\
\hline & Dhaka (4) & 25.6 & & & \\
\hline & Local and Dhaka (6) & 18.6 & & & \\
\hline \multirow{3}{*}{ Mortality of birds } & Low (1-100) & 67.4 & \multirow{3}{*}{$12-500$} & \multirow{3}{*}{113.86} & \multirow{3}{*}{47.7} \\
\hline & Medium (101-200) & 18.6 & & & \\
\hline & High (201 and above) & 14.0 & & & \\
\hline
\end{tabular}

\section{Price per $\mathrm{kg}$ feed}

The price/kg feed before flood was maximum Tk. 18 and minimum Tk. 16 and on an average it was 17.02 with a standard deviation of 0.59 . Among the respondents, about $62.8 \%$ farmers bought the feed on medium price i.e. Tk. $17.0-17.9 / \mathrm{kg}$ whereas after flood it was increased and most of the farmers (72.21\%) had to buy with the high price (Tk. 18/kg and above). The average price per $\mathrm{kg}$ feed was Tk. 17.69 and the standard deviation was 0.5 after flood (Table 3).

\section{Price per kg broiler}

Before flood, $60.5 \%$ of the farmer got good price (Tk. 55-58/kg), 27.9\% got better price Tk. 58.60/kg and $11.6 \%$ got best price (60 and above) which was ranged from Tk. 55-65/kg and on average Tk. $58.5 / \mathrm{kg}$ broiler. Its standard devition was 3.03 . After flood victim, it was reported that the maximum price of broiler $/ \mathrm{kg}$ was Tk. 55 and minimum Tk. 35 with a mean of Tk. 44.4/kg and standard deviation 6.08 (Table 3). It was very much lower than the normal price. 
Bang. J. Anim. Sci. 2008, 37 (1)

Table 3. Economic status of broiler farms before and after flood

\begin{tabular}{|c|c|c|c|c|c|c|c|c|c|c|c|}
\hline \multirow{2}{*}{$\begin{array}{c}\text { Characteris } \\
\text { tics }\end{array}$} & \multicolumn{5}{|c|}{ Before flood } & \multicolumn{6}{|c|}{ After flood } \\
\hline & Categories & \begin{tabular}{|c|} 
Respondent \\
$(\%)$
\end{tabular} & $\begin{array}{l}\text { Observed } \\
\text { score }\end{array}$ & Mean & SD & Categories & Res! & \begin{tabular}{l|l|}
$\%)$ \\
\end{tabular} & $\left|\begin{array}{c}\text { Observ } \\
\text { ed score }\end{array}\right|$ & Mean & SD \\
\hline \multirow[b]{2}{*}{ Cost/chick } & $\begin{array}{l}\text { Tk. } \\
\text { 17/chick }\end{array}$ & 32.6 & \multirow[b]{2}{*}{$17-18$} & \multirow[b]{2}{*}{17.67} & \multirow[b]{2}{*}{$\begin{array}{c}0.4 \\
7\end{array}$} & \multicolumn{3}{|c|}{$\begin{array}{l}\text { Low increased } \\
\text { (Tk. 19) }\end{array}$} & \multirow[b]{2}{*}{$19-20$} & \multirow[b]{2}{*}{19.5} & \multirow[b]{2}{*}{0.5} \\
\hline & $\begin{array}{l}\text { Tk. } \\
\text { 18/chick }\end{array}$ & 67.4 & & & & $\begin{array}{l}\text { Highly } \\
\text { increased ( } \\
20)\end{array}$ & Tk. & 55.8 & & & \\
\hline \multirow{3}{*}{$\begin{array}{l}\text { Price } / \mathrm{kg} \\
\text { feed }\end{array}$} & $\begin{array}{l}\text { Low } \\
\text { (Tk. 16- } \\
16.9)\end{array}$ & 18.6 & \multirow{3}{*}{$16-18$} & \multirow{3}{*}{17.02} & \multirow{3}{*}{$\begin{array}{c}0.5 \\
9\end{array}$} & \multicolumn{2}{|c|}{$\begin{array}{l}\text { Low (Tk. 16- } \\
16.9)\end{array}$} & 7.0 & \multirow{3}{*}{$16.6-18$} & \multirow{3}{*}{17.69} & \multirow{3}{*}{0.5} \\
\hline & $\begin{array}{l}\text { Medium } \\
\text { (Tk. 17- } \\
17.9)\end{array}$ & 62.8 & & & & $\begin{array}{l}\text { Medium (1 } \\
17-17.9)\end{array}$ & & 20.9 & & & \\
\hline & $\begin{array}{l}\text { High (Tk. } \\
18 \text { and } \\
\text { above) }\end{array}$ & 18.6 & & & & $\begin{array}{l}\text { High (Tk. } \\
\text { and above) }\end{array}$ & & 72.1 & & & \\
\hline \multirow{3}{*}{$\begin{array}{l}\text { Price } / \mathrm{kg} \\
\text { broiler }\end{array}$} & $\begin{array}{l}\text { Good price } \\
\text { (Tk. 55-58) }\end{array}$ & 60.5 & \multirow{3}{*}{$55-65$} & \multirow{3}{*}{58.5} & \multirow{3}{*}{$\begin{array}{c}3.0 \\
3\end{array}$} & $\begin{array}{l}\text { Low price } \\
35-45)\end{array}$ & (Tk. & 67.4 & \multirow{3}{*}{$35-55$} & \multirow{3}{*}{44.4} & \multirow{3}{*}{$\begin{array}{c}6.0 \\
8\end{array}$} \\
\hline & $\begin{array}{l}\text { Better price } \\
\text { (Tk. 58-60) }\end{array}$ & 27.9 & & & & $\begin{array}{l}\text { Medium p1 } \\
\text { (Tk. 46-54 }\end{array}$ & & 23.3 & & & \\
\hline & $\begin{array}{l}\text { Best price } \\
\text { (Tk. } 60 \text { and } \\
\text { above) }\end{array}$ & 11.6 & & & & $\begin{array}{l}\text { High price } \\
\text { (Tk. } 55 \text { an } \\
\text { above) }\end{array}$ & & 9.3 & & & \\
\hline
\end{tabular}

\section{Economic loss in relation to flood}

From the cost analysis, it was reported that the chick cost increased due to flood was Tk. 1-3/chick with a mean of Tk. 1.88/chick and standard deviation 0.54. Among the respondents, most of them $(69.8 \%)$ faced the problem of medium increased price (Tk. 2.0-2.9/chick) after the flood. About $58.1 \%$ of the farmers faced high economic loss per $\mathrm{kg}$ feed whereas $7 \%$ faced medium loss and $34.9 \%$ faced no loss due to flood (Table 4).

The average loss per $\mathrm{kg}$ broiler was Tk. 14.11/kg which ranged from Tk. 5-23/kg and standard deviation 5.87. Most of the farmers (72.6\%) faced a high loss (Tk. 13 and above/kg) during selling of the broiler after flood. In respect of overall economic loss, most of the farmers $(51.2 \%)$ faced high loss (Tk. 1500 and above), 16.3\% faced low (Tk. 200-1400) economic loss due to flood. On the other hand, about $32.5 \%$ farmers obtained a small amount of profit (Tk. 200 and above). It was also revealed that the broiler farmers obtained a profit up to Tk. 3000 and faced a massive loss up Tk. 25000 Tk. with an average of Tk. -3413.95 and standard deviation 481.93 (Table 4). 
Table 4. Analysis of economic loss in relation to flood

\begin{tabular}{|c|c|c|c|c|c|}
\hline Characteristics & Categories & $\begin{array}{c}\text { Respondent } \\
(\%)\end{array}$ & $\begin{array}{l}\text { Observed } \\
\text { score }\end{array}$ & Mean & $\begin{array}{c}\text { Standard } \\
\text { deviation (SD) }\end{array}$ \\
\hline \multirow{3}{*}{ Loss/chick } & Low (Tk. 1-1.9) & 20.9 & \multirow{3}{*}{$1-3$} & \multirow{3}{*}{1.88} & \multirow{3}{*}{0.54} \\
\hline & Medium (Tk. 2-2.9) & 69.8 & & & \\
\hline & High (Tk. 3 and above) & 9.3 & & & \\
\hline \multirow{3}{*}{ Loss $/ \mathrm{kg}$ feed } & No loss (Tk. 0) & 34.9 & \multirow{3}{*}{$0-2.00$} & \multirow{3}{*}{0.6698} & \multirow{3}{*}{0.54} \\
\hline & Low loss (Tk. 0.1-0.5) & 7.0 & & & \\
\hline & High loss (Tk. 0.6 and above) & 58.1 & & & \\
\hline \multirow{3}{*}{ Loss/kg broiler } & Low (Tk. 5-9) & 20.9 & \multirow{3}{*}{$5-23$} & \multirow{3}{*}{14.11} & \multirow{3}{*}{5.87} \\
\hline & Medium (Tk. 10-12) & 7.0 & & & \\
\hline & High (Tk. 13 and above) & 72.1 & & & \\
\hline \multirow{3}{*}{$\begin{array}{l}\text { Overall economic } \\
\text { analysis }\end{array}$} & Profit (Tk. 200 and above) & 32.5 & \multirow{3}{*}{$\begin{array}{l}3000- \\
25000\end{array}$} & \multirow{3}{*}{-3413.95} & \multirow{3}{*}{481.93} \\
\hline & Low loss (Tk. 200-1400) & 16.3 & & & \\
\hline & High loss (Tk. 1500 and above) & 51.2 & & & \\
\hline
\end{tabular}

The main causes of economic loss during and after the flood were identified as :

- Availability of day old chick became squeezed and cost/chick became high.

- Inadequate supply of broiler feed.

- High transportation cost.

- No scope to tranfer the immature broiler from the shed of lower to higher land and had to sell the birds at a lower price.

- Marketing problem.

- Frequent electricity failure.

- More disease prevalance in the flood affected areas.

- Lack of knowledge to overcome the flood problem.

Uddin (1999) also showed that the broiler farmers and traders faced various problems such as high transportation cost, inavailability of chick, inadequate veterinary service, high feed cost, uncertainly electricity failure, high mortality of broilers, inadequate marketing facilities, lack of capital, lack of training facilities and lower market price. In another study, Miah (1990) reported that the small and medium poultry farms are profitable but acute shortage of medicine, lack of technical know-how together with resource content were observed as the major constraints of those poultry farms.

\section{Relationship of selected characteristics of farmers and other factors with economic loss of flood victim broiler farms}

To investigate the effect of education, family size, occupation, farm size, feed sources, types of vaccine and medicine used and marketing place of broiler on the economic loss of flood victim broiler farms, correlation co-efficient values (r) were analyzed (Table 5). From the correlation analysis, it was reported that family size $(-0.138)$, occupation $(-0.152)$, feed sources $(-0.125)$ and types of vaccine used (-0.08) had no significant relationship but education (-0.322), farm size (-0.517), types of medicine used $(-0.417)$ and marketing place of broiler $(-0.538)$ had significant $(\mathrm{p}<0.01)$ relationship 
Bang. J. Anim. Sci. 2008, 37 (1)

with economic loss of flood victim broiler farms. As marketing place of broilers, farm size and medication had a higher significant correlation with the economic loss of flood victim broiler farms, so farmers had to be conscious about these. So, farmers are advised to increase farm size and marketing place of broilers because when farm size and marketing place of broilers were increased, the economic loss will be decreased. Education also decreased the economic loss of broiler farms because educated farmers might possess knowledge and skillness to overcome the flood problem.

Table 5. Correlation analysis between dependent (Economic loss of flood victim broiler farms) and independent variables

\begin{tabular}{|c|l|c|}
\hline \multirow{2}{*}{ SI. No. } & \multicolumn{1}{|c|}{ Independent variable } & Dependent variable \\
\cline { 3 - 3 } & & Economic loss of flood victim broiler farms \\
\hline 1 & Education & $-0.322^{*}$ \\
3 & Family size & -0.138 \\
4 & Occupation & -0.152 \\
5 & Farm size & $-0.517^{* *}$ \\
6 & Feed sources & -0.125 \\
7 & Types of vaccine used & -0.08 \\
8 & Types of medicine used & $-0.417^{* *}$ \\
\hline
\end{tabular}

* Significant $(\mathrm{P}<0.05), * *$ Significant $(\mathrm{P}<0.01)$

\section{Recommendation}

On the basis of economic loss of broiler farms after flood, the following measures should be taken :

- The farmers should take all the precautionary measures like establishment of poultry shed at high land providing adequate drainage facilities to smooth run off water in the flood victim areas.

- Extension services should be provided in respect of poultry biosecurity, feeding, brooding, medication and control of diseases in the flood victim areas.

- Systemic training programme need to be taken for better management of broiler farms during and after flood.

- Medicine and vaccine should be available after flood.

- Communication and transportation system should be developed to improve the efficiency of poultry marketing system.

\section{Conclusion}

Due to flood, most of the farmers had to buy the day old chick and feed at a higher price. They had to sell the broilers at a lower price than before flood. As a result, they faced a great economic loss. On 
the other hand, the economic loss of flood victim broiler farms had a significant negative correlation with farm size, marketing place of broilers, types of medicine used and education of farmers. The most serious problems identified in the flood affected areas were high chick, feed and transportation cost and also inadequate marketing facilities. So, to make this enterprise profitable, government and NGO's should take precautionary measures as well as provide loans without interest to the flood victim broiler farms.

\section{Literature Cited}

BBS, 1998. Statistical Year Book of Bangladesh. Banglasesh Bureau of Statistics, Statistics Division, Ministry of Planning, Government of the People's Republic of Bangladesh. pp. 25-32.

Jabbar, M. A. and Green, D. A. G. 1983. The status and potential of livestock within the contact of agricultural development policies in Bangladesh. Aberysthth, The University College, Wales, UK. pp. 110-116.

Miah, S. 1990. Economics of commercial poultry farming in Bangladesh, Bureau of Socio-economic Research and Training, Bangladesh Agricultural University, Mymensingh, Bangladesh. Report No. 21.

Uddin, M. S. 1999. A study on marketing broilers in selected areas of Mymensingh district. M.S. Thesis. Department of Co-operation and Marketing. Bangladesh Agricultural University, Mymensingh. 